University of Wollongong

Research Online

Faculty of Social Sciences - Papers (Archive) Faculty of Arts, Social Sciences \& Humanities

2017

Subcultural enterprises, brand value, and limits to financialized growth: The rise and fall of corporate surfing brands

Andrew T. Warren

University of Wollongong, awarren@uow.edu.au

Christopher R. Gibson

University of Wollongong, cgibson@uow.edu.au

Follow this and additional works at: https://ro.uow.edu.au/sspapers

Part of the Education Commons, and the Social and Behavioral Sciences Commons

Research Online is the open access institutional repository for the University of Wollongong. For further information contact the UOW Library: research-pubs@uow.edu.au 


\title{
Subcultural enterprises, brand value, and limits to financialized growth: The rise and fall of corporate surfing brands
}

\author{
Abstract \\ Geographical political economy increasingly scrutinises the socio-spatial contexts for brands and \\ branding. Less understood is the influence of subcultures - neo-tribal groups sharing passions, a leisure \\ pursuit or practice - on enterprise formation and the pathways through which brands emerge, trading on \\ perceived authenticity. Subcultural contexts, we argue, unleash distinctive trajectories of enterprise \\ formation, reputation-building, value-creation, global expansion and accumulation, and ultimately \\ destruction. Here we focus on how particular subcultural values - of authenticity, competition, risk-taking, \\ and active participation in 'scenes' - interact with capitalist growth dynamics, and where over time and \\ space such intersections bring brands unstuck. Using the case of surfing subculture and collapse of \\ corporate surf enterprises (Quiksilver, Billabong), we theorise subcultural brand value creation and its \\ interaction with financialized expansion, culminating in destructive contradictions. Subcultural enterprises \\ with 'authentic', 'back-of-the van' origins convert subcultural values of credibility, localism, risk-taking, and \\ scene participation into brand value. Trading on place-origins and subcultural authenticity, enterprises \\ expanded in two phases. First by widening distribution using specialist 'surf' retailers, and second by \\ offshoring production, public floating, and debt-financing brand acquisitions and massive retail \\ expansion. Dictates of shareholders and investment banks spurred market saturation, and high-volume/ \\ low-quality goods. Surfing's cherished insouciance gave way to unhinged expansionism and \\ unmanageable debt. The subcultural authenticity that spawned brand popularity was undermined, \\ amplifying financial risk. Disenchanted consumers who once co-created successful brands also co- \\ destroyed them. As subcultural brands proliferate, geographical political economy must be attentive to \\ subcultures as spawning-grounds for enterprises with accompanying limits to market growth, \\ (dis)connections, and values.
}

\section{Keywords}

fall, rise, growth:, financialized, surfing, limits, corporate, value, brand, enterprises, subcultural, brands

\section{Disciplines}

Education | Social and Behavioral Sciences

\section{Publication Details}

Warren, A. \& Gibson, C. (2017). Subcultural enterprises, brand value, and limits to financialized growth: The rise and fall of corporate surfing brands. Geoforum, 86 177-187. 


\section{Introduction}

In September 2015, multinational surf brand Quiksilver (ZQK, New York Stock Exchange) began Chapter 11 federal bankruptcy proceedings in a Delaware court (U.S. Bankruptcy Court 15-11880). Within three years, Quiksilver's annual revenue had fallen 30\% and debt had increased beyond US\$800 million. Fellow multinational surfing label Billabong (BBG, Australian Stock Exchange) was also in crisis, having just faced a messy US\$350 million restructure in 2014. The founders of Rip Curl, the third of the 'Big Three' global surf brands, proposed and then abandoned a $\mathrm{A} \$ 400$ million sale amidst falling profitability, leading to the high profile exit of its Chairperson (Greenblat 2014). The restructuring of these global brands encompassed take-overs by private equity consortiums, dilution of shareholder ownership, major losses for creditors, the fire sale of subsidiary brands, and large job cuts across production networks. Once at the core of a seemingly ever-expanding international market for clothing and apparel, surf megabrands became pariahs of international retailing, stripped of their 'cool' cachet, and subject to continual admonition from business analysts and commentators.

Much broadsheet commentary surrounded the crisis of corporatised surf enterprises. It largely interpreted collapse through frames familiar in international political economy. Blamed were spiralling debts, contracting consumer spending following the global financial crisis (GFC), merry-go-round volatility within corporate boardrooms, and poor management strategy leading to a loss of legitimacy within capital markets (cf. Khouri 2015). Such narratives are consistent with economic geographic analyses of the debt-financed global expansion of transnational firms and accompanying crises (Fagan and Le Heron 1994; Wood et al. 2016). But they only partially explain the collapse of corporate surf brands. Here we seek to provide a fuller account that integrates a geographical political economic analysis of financialized growth with factors arising from the subcultural origins of enterprises themselves: origin/formation narratives, value creation and destruction, and subsequent collapse not just in debt and risk but also brand legitimacy. We emphasise interactions and tensions between market logics of global expansion and capital accumulation and grounded subcultural values of authenticity, risk-taking, competition, and social connections within subcultural 'scenes'.

Values that infuse subcultures include origin narratives: enterprises having originated from within a genuine place-based ‘scene’ of participants espousing countercultural practices. These are groups of intense and passionate consumers with shared interests or pursuits, sometimes referred to as 'neotribes' (Cova et al. 2007). Such countercultural values provide profitable opportunities for enterprises that stem from subcultural origins, such as music, fashion, and surfing, and underpin brand value creation as they scale-up from localised, grass-roots beginnings to global production and distribution networks (cf. Yeung 2014). Increasingly, 
geographical political economy is scrutinizing the socio-spatial contexts of brands and branding including strategies to market commodities via origin narratives and place connections (cf. Pike 2015; Yeung 2016; Crewe 2017). But rarely integrated into economic geographies of brands and branding is the influence of subcultural contexts and values. Indeed, subcultures are rarely taken seriously within academic economic geography (for exceptions see: Bader and Scharenberg 2010; Lange and Burkner 2015). Examining the case of collapse among corporatised surf brands, we theorise how dynamics relating to global expansion, financialisation, and accumulation pathways interact with subcultural value creation and brand authenticity to unleash destructive tensions.

Supporting our argument is empirical detail collected within a broader research project concerned with crises in the surf industry. Between 2008 and the present we have pursued a longitudinal study of the surf industry. More than 200 interviews with key actors in the industry have been conducted to date, collecting 600 hours of audio recordings. These have included direct employees of the Big Three surf brands, contracted surfboard manufacturers, surf clothing designers, apparel retailers, surf media figures and representatives from the Surf Industry Manufacturers Association (SIMA). Our analysis below draws on these sources. Additionally, historical information was collected from archives held at the Surf Heritage Foundation (California), Surf World Museums (Victoria and Queensland) and Bishop Museum of Polynesian Cultural Heritage (Honolulu). Quantitative data on Quiksilver and Billabong were compiled using publicly available financial reports statements to investors (2005-2015). Transcripts from 34 investor meetings with Billabong (2001-2015) and Quiksilver (1997-2015) executives were also analysed. As Rip Curl is privately owned, financial information was triangulated using print media, company statements, and our own interviews with employees. From these empirical observations, a picture emerges of how global expansion, debt, and risk interacted with the subcultural groundings of surf brands.

Accumulation pathways for surf brands emerged from the possibilities of selling a 'cool' lifestyle and subversive semiotic meanings to consumers beyond the subculture (Lawler 2012). Surfing's connotations as care-free, insouciant and countercultural offered a potent commercial package (Warren and Gibson 2014). Subcultural commodification occurred in successive waves: first in Hawai'i, where it accompanied tourism marketing, and second in California where it was used to promote hotels and real estate (Warshaw 2010; Shaw and Menday 2013). Then in the 1950s the globalisation of surfing intensified, via American music, film and television shows, spreading to Australia, Europe and beyond. From the 1960s, internationalisation enabled nascent equipment, fashion and apparel industries to emerge. Our empirical analysis elucidates such phases, focusing especially on the latter period, when local surfing subcultures bred enterprises 
that became iconic brands, and then multinational corporations. Early entrepreneurs from Australian coastal towns developed equipment and apparel brands, establishing early distribution and retail networks. Rarity value for surf products accrued through restricted availability. As brand reputation propagated, licensing agreements, distribution rights and retail networks expanded into more locations and outlet types (including shopping malls). Surfing's insouciance, competitive spirit, and 'culture of risk' (Walton and Shaw 2016), permeated enterprise strategies and expansion. The balance of profits derived not just from core equipment (surfboards, wetsuits), but increasingly from general fashion items - t-shirts, sunglasses, swimwear - with wider consumer appeal. Debt-financing, vertical integration, standardisation, acquisition and diversification strategies followed. By 2005, Quiksilver and Billabong were billion-dollar enterprises, listed on stock exchanges in New York and Sydney. Surfing subculture grew to underpin a US\$13 billion global industry (Global Industry Analysts 2016). Once 'grounded' in subversive counterculture, surf enterprises became highly financialised corporations with standardised production, marketing, and distribution networks.

However, the deepening integration into global circuits of financial capital, product homogenisation, and pursuit of endless growth to satisfy shareholders, progressively undermined the subcultural origin narratives, and values of surfing credibility and participation that were key to market value. Alongside faltering legitimacy (cf. Wood et al. 2016), corporatised surf brands experienced declining sales, falling profit margins, and unserviceable levels of debt. Capitalist principles of market expansion, economies of scale, and increasing sales volumes collided with anti-establishment values, the need for authenticity, and origin narratives that connected brands to local subcultural scenes (cf. Driver 2011; Beaumont and Brown 2015). Corporatisation and debtfuelled expansion approached and then exceeded certain limits, jeopardizing the enterprises financially, but also undermining subcultural legitimacy. The collapse of brand authenticity in turn afforded opportunities for renaissance localism, and space in the market for new niche players with more credible subcultural connections. Through the case of surfing, we explicate broader implications for understanding subcultural origin narratives, enterprise formation, brand value, and expansion under global capitalism.

After surveying and linking relevant literatures on the economic geography of brands and commercial salience of subcultures our analysis is structured in two main parts. First, from research on the surfing industry (with workers, firms, and consumers) we trace accumulation pathways, examining how waves of subcultural commodification and marketisation evolved. Packaged into clothing, apparel and fashion products, surfing came to embody a highly profitable industry. Adding to critiques of orthodox economic knowledges predicated on naturalised market relations, we examine the 'market shape' surfing subculture spawned (Polanyi 1977). Subcultural 
groundings shaped brand values, market strategies, and initial expansion (cf. Jessop and Sum 2010). Subcultural values and meanings permeated the entire production system: from the design and manufacture of clothing/apparel, to commercial business dealings and retail stores selling branded goods. Early international expansion tapped into emerging specialist surf retail networks. Surf firms were initially created and led by surfers, whose passion for the sport, connections to the subculture and proclivities for risk-taking were atypical to the corporate managerial class. The result was a collection of brands reaching a certain market size that held subcultural credibility in tension with growing geographic and market reach.

Second, we explore interactions between the subcultural groundings of enterprises and processes of capitalist expansion, debt financing and risk. While acknowledging the global financial crisis impacted negatively upon surf brands and fashion retail (cf. Crewe 2017), we detail longer-run contingences and outcomes, emanating from the subcultural contexts of surfing brands. Our argument is the roots of collapse stretch further back, to historical attempts to commercialise surfing, and to the place-and time-specific evolution of subcultural enterprises. We trace the market tactics of surf enterprises following early international distribution, including public listings, and pursuit of vertical integration, acquisition, diversification, and high-volume growth strategies. Although consistent with the subculture's risk-taking ethos, such tactics strayed from values of authenticity, localism and scene participation that underpinned the identity and legitimacy of each brand. Increasingly, surf firms mimicked tactics of mainstream department stores, including homogenising product design globally (diluting local subcultural variants) and debt-financing expansion into mass-retail, hoping for dominant market share. Corporatised firms dependent on subcultural origin narratives for value creation became lockedin to obligations of market expansion, compound growth and shareholder dividends - all of which undermined subcultural authenticity. At its heart, surfing remained subcultural, where credibility equated to pursuit of oceanic lifestyles (Lawler 2012), and links to coastal geographic origins (Warren and Gibson 2014). After floating, appointments of mainstream retail executives and global market saturation, surf brands witnessed a collapse in legitimacy and thus value. First surfers, as key subcultural gatekeepers, and then general consumers, became dismissive of surf brands selling poor-quality, mass-market goods. Fading cool factor diluted marketing campaigns, poor quality products reduced reputations, and brand saturation in shopping malls and department stores destroyed vestiges of rarity value. As sales and profit margins declined, debts spiralled to unmanageable levels. Subcultural values ultimately limited the mass-market penetration of surfing brands, illustrating the unstable relationships between subcultural enterprises, brand value, and corporatised growth. 


\section{A geographical political economy of subcultural brands}

Economic geographers increasingly scrutinise the socio-spatial contexts of capitalist brands and branding (Pike 2009; Tokatili 2014; Crewe 2017). At the heart of this emergent research program are questions about how brands and their connected geographic and social relations create meaning and value that is circulated and scaled through the work of various actors (designers, makers, marketers, retailers, end-consumers). Historical analysis of brands has helped develop a stronger understanding of the connections between branded objects and the social relations that laden them with meaning and value (Gibson and Warren 2014). Research has also revealed how contemporary brands powerfully direct where and how commodities are designed, made, valued, circulated and exchanged (Moor 2007; Pike 2009; Crewe 2017). In hyper-competitive retail markets brands must create value and legitimacy, while ensuring transferability across time and space. Brands and branding practices thus involve both material and immaterial elements (Pike 2015). Branded products are commodities represented by a price paid by consumers. At the same time brands elicit emotional and embodied responses from consumers as their products are marketed and become identified as signifiers of quality, social status, taste, and meaning (Crewe 2003; Pike 2015).

This geographical scholarship has advanced understandings of the power of place in relation to brand value, and revealed the multiscalar lives of brands themselves (Jackson 2004; Pike 2015; Crewe 2017). Nevertheless, some themes remain underdeveloped. These include limited analysis of the actions and agency of consumers who co-create brands (from their genesis in local places to global ubiquity) and contribute to their longer-run market fate (Crewe 2003; Hracs et al. 2013). Below, the role of consumers who co-create and co-destroy brands is discussed. Looming even larger as an overlooked theme in research on the geographies of branding is the role of subcultural origins, meanings, and values. Despite the commercial potency of subculture (from gaming and grunge music to surfing and sci-fi), economic geographers have rarely extended analytical focus to the intersection of subcultural activities, brands and place. We contribute to the economic geography of brands and branding by taking subcultures seriously as a source of enterprise formation, semiosis, value creation, and profit-making. Our focus on surfing-based enterprises offers insights into the market potential of subcultural enterprises, and the limits to growth for such brands and branded products.

To this task, we bring a conceptual approach from geographical political economy (GPE), with a focus on the market shape of commodity producing brands (Polanyi 1977), and how the 'spatialities of capitalism co-evolve with its economic processes... increas[ing] agents' uncertainty and the likelihood of unintended consequences’ (Sheppard 2011: 319). Further influence stems from cultural political economy that explicitly attends to the process of semiosis 
or 'meaning-making' (Jessop and Sum 2010: 445; Hudson 2012), and subcultural theory - a pursuit of sociology and cultural studies seldom incorporated into economic geography (Lange and Burkner 2015). This conceptual synthesis helps analyse how subcultural origins give rise to capitalist enterprises with certain characteristics and accumulation pathways (cf. O’Neill and Gibson-Graham 1999), generating opportunities for brand value creation and large profits but also unleashing inherent contradictions that limit global homogenisation and undermine longerterm corporate stability (cf. Harvey 2014). We demonstrate how values emanating from a subculture intertwine with brand formation, market imperatives, and processes of capital accumulation. This linking of the subcultural and capitalistic spawned contradictions, as enterprises grew, became iconic brands trading on authenticity, expanded globally, and took on the profile of financialised transnational corporations. In short, surf capitalism emerged through the evolution of a distinctive 'market shape of things' (Polanyi 1977: xl) intimately linked to surfing subculture (Lawler 2012), accumulation pathways pursued by enterprises, and their subsequent over-reach within globalised and financialised circuits of capital. ${ }^{1}$

Surfing's subcultural values - emphasising local origins, authenticity, and scene participation - delivered opportunities for commodification, brand formation, value creation and accumulation (Lawler 2012). But also, critically, the same subcultural values unleashed deeper contradictions when enterprises fully embraced the logics of global, corporate capitalism (public listing, product standardisation, market saturation). We connect with recent geographical political economy analyses of brands and retailing (Pike 2015; Crewe 2017), while incorporating insights from subcultural theory. The subcultural origins of surf brands and their particular accumulation pathways are crucial to fully explaining the character of enterprise formation, brand value, subsequent contradictions and collapse. In theorising subcultural enterprises, we elide stable, rational or homogenous conceptions of firms (cf. O’Neill and Gibson-Graham 1999). Rather, subcultural enterprises are commercial entities trading on value that arises from a brand's origin narratives in distinctive socio-spatial scenes. They encapsulate dynamic power relations, competing representations and contradictory narratives between actors: executives, workers, politicians and consumers. We illustrate with examples of competing narratives, values and contestation among founding entrepreneurs and later corporate executives that shaped subcultural enterprise formation, market expansion and eventual failure.

In describing the 'market shape' for surf capitalism, we also draw upon multidisciplinary literatures concerned with meanings and processes that commodify and marketise subculture. Subcultures are formed by people who pursue a common passion, share peculiar codes of dress and language, and interact socially in physical or online spaces (Pearson 1979; Thornton 1995; Cova et al. 2007). A significant thread of scholarship has traced subcultures as social formations. 
With origins in the 'Birmingham School' of cultural studies in the 1970s (cf. Hall and Jefferson 1975), subcultural theory had developed from studies of punk, rave and heavy metal music scenes, which espoused countercultural stances (Pearson 1979; Cova et al. 2007). Distinctive values influence how meaning is generated within subcultures, which frequently operate as sociospatial 'scenes' with strong connections to particular places (increasingly mediated by internet technologies), within which participation is policed by gatekeepers (McRobbie 1998). Credibility is paramount. Counter-cultural attitudes inform shared practices, behaviours and spatial preferences. Distinctive dress codes, gender relations, social mores and language emerge, with the presentation of the self-paramount to acceptability and the policing of in-group/out-group boundaries (Thornton 1995; Anderson 2016). Social relationships and knowledge of trends and key local sites become essential to participation and credibility.

As sign values became increasingly relevant to market strategies (Lash and Urry 1994), subcultures offered visual cues and cultural meanings for commodity production and marketing; their 'look' and 'cool factor' incorporated into television shows and mainstream advertising campaigns. Palmås (2014: 1301) argues that subcultures such as surfing, 'based on subterranean values', have become drivers of Schumpeterian creative destruction. Within capitalist markets subversive values and virtues become imperatives for profit-making. Subcultural language, visual codes and signifiers of place and 'authenticity' provide options for advertisers to sell everything from soft drinks to real estate (Warren and Gibson 2014).

Multiplication of subcultural scenes across countries (Usher and Kerstetter 2015), and growing internet mediation, have also created opportunities for global niche marketing linked to origin stories. Brands stemming from 'authentic' local roots (e.g. Seattle record labels, L.A. street fashion) internationalise sales by leveraging credibility and cachet associated with their geographic origins, and 'grass-roots' participation in the subculture. Goods sold through subcultural enterprises constitute not only necessary equipment for participation (e.g. surfboards, skateboards, electric guitars), but emblems of loyalty and affiliation to brands and wider subculture. In time, many such enterprises, growing from local origins to trade through global (niche) networks, branched out into other product lines - t-shirts, shoes, sunglasses - where the logo, place association, and related subcultural cachet, proved extremely profitable.

Surfing is one of the more enduring, and lucrative, subcultures. With origins in Hawai'i, and subsequent growth of the subculture in the United States, Australia, Brazil, Central America, Japan and elsewhere, surfing has consistently espoused subterranean values (Palmås 2014; Usher and Kerstetter 2015). Surfers embrace an oceanic 'culture of risk' (Walton and Shaw 2016: 1), and express non-conformist, antithetical attitudes towards the usual beacons of rational economic behaviour: a stable job, private property ownership, personal wealth creation (Warren and Gibson 
2014). Yet, surfing subculture entered mainstream popular culture in the United States and was intensively commodified from the 1960s (Lawler 2012). We analyse the manner in which waves of commodification appropriated surfing's countercultural values, while the subculture's appetite for risk spawned accumulation pathways for nascent enterprises (in time becoming corporate giants). In the extant literature on the commodification of surfing subculture, little acknowledgement is given to how subcultural values become incompatible with, and indeed destructive of, corporate growth models. Geographical and sociological scholarship is exploring the phenomenon of localism within surfing subcultures (Usher and Kerstetter 2015), but how such values contradict the increasingly global, homogenising market saturation of brands emanating from local surfing origins, remains underexplored. We extend such scholarship by focusing on brand authenticity, origin narratives and accumulation pathways arising from subcultural origins and the inherent contradictions and limits of subcultural brands.

\section{Surfing subcultures: revisiting origin narratives}

Surfing originated with Hawaiians who since approximately 800AD have used specialised boards to ride waves to shore (Finney and Houston 1996). From initial contact, Western colonisers of Hawai' $i$ typecast surfing as a subversive activity, considering it a hindrance to establishing the institutions of Christianity and capitalism (Walker 2011). Hawaiian society was perceived 'as antithetical to the European developments of Christianity, capitalism, and predatory individualism as any society could have been’ (Trask 1996: 4). For Hawai ‘i to be rendered a landscape of private enterprise and profit via expansion of sugar and pineapple plantations, 'antithetical' values, embodied by surfing needed recalibrating. Because American capitalists required commodified local labour throughout the nineteenth century, surfing - seen as risky, 'distracting', lackadaisical - was actively discouraged.

Annexation by the U.S. in 1898, and concerted marketing of the islands as a trade, tourism, and migration destination, resulted in various aspects of Hawaiian culture - hula, surfing, ukulele playing - being subject to exoticised commodification (Imada 2012). Surfing provided ready-made sensual imagery for a burgeoning colonial tourist gaze. Demand quickly developed for surfing among tourists and foreign immigrants permanently settling in Hawai' $\mathrm{i}$. Boosters of Hawai'i such as Alexander Hume Ford also began using surfing imagery (in newspaper and magazine advertisements) to promote land sales, hotels, and aloha spirit (Warshaw 2010). In the early twentieth century, Hawaiian surfers George Freeth and Duke Kahanamoku embarked on extended tours of the U.S. mainland and Australia, providing surfing demonstrations to public beach-goers (Warren and Gibson 2014). In southern California Abbot Kinney and Henry Huntington used surfing demonstrations by the Hawaiians to promote private 
railway services, hotels and coastal housing developments (Warren and Gibson 2014). After World War II, surfing scenes in Hawai‘i, Australia’s east coast and America’s west coast developed a more visible presence. Surfing emerged as a subculture defined by risky behaviour, and the unique dress, language and style of its members (cf. Pearson 1979). Because surfers spent long periods of time at the beach rather than a workplace, they attracted social controversy (Lawler 2012). Surfers rejected conventional social values of discipline and a stable job. According to Booth (2005) surfers were typecast by print media as 'dole-bludging troublemakers’ and ‘jobless junkies roaming beaches’. Surfing courted and celebrated a reputation as an audacious and oppositional practice.

Despite rejecting mainstream values the subculture quickly popularised. Surfing had youthful exuberance, a laid-back lifestyle, distinctive music, sunny beaches, and suntanned bodies. An oppositional subculture provided advertisers and media industries with a potent commercial blend of 'youth cool' and sun-kissed imagery. Hence by the early 1960s there was:

A popular obsession with all things surf... Surf music, surf clothing, even surfboards on the roof of cars in landlocked middle America - the kids couldn't get enough of the surf lifestyle, and Hollywood, the music industry, and the new surfboard and surf wear companies couldn't serve it up quickly enough. And with every magnification of the surf image in American pop culture, the number of actual surfers increased exponentially. (Lawler 2012: 2)

Surfers set themselves apart by routinely rejecting mainstream economic notions of work, ambition and routine. Nonetheless, hedonistic visual imagery combined with surfing's physical emblems afforded new opportunities to commoditise and profit from the subculture.

\section{Local origins: the formation and rise of the 'Big Three' surf brands}

Initial popular interest in surfing benefitted equipment and hardware manufacturers. In the 1960s commercial surfboard factories multiplied in coastal towns where surfing was widely practiced: San Clemente and Santa Cruz in California, O‘ahu’s North Shore, and Sydney’s Northern Beaches, Torquay on the Victorian coast, and Queensland's Gold Coast in Australia. Factories were typically small enterprises, employing a handful of workers and selling boards to mostly local customers. Labour was drawn from within local surfing scenes with the best local surfers often given jobs designing and marketing surfboards, ensuring a level of foot traffic into retail showrooms (Warren 2014). High level of embeddedness within local surfing subculture underpinned financial viability. A craft-based, manual labour process evolved, with restricted production volumes, tight margins and limited capacity to expand markets. The market dynamics of surfboard manufacturing were also influenced by the physical geography of local surf breaks with board designs matched to both riders and characteristics of local waves. 
From surfboard factories, limited in market size, emerged a series of standalone surfwear enterprises. The earliest were California-based O’Neill (1952) and Hang Ten (1960); start-ups from enthusiastic surfers seeking to generate income in support of surfing lifestyles (Warshaw 2010). Across the Pacific and emerging from the small Australian town of Torquay, were surf labels that would become multi-billion dollar international brands (cf. Stewart et al. 2008). By the late 1960s, Torquay was a hub for surfing with numerous high-quality breaks (notably Bells Beach). In 1968, Torquay surfers Brian Singer and Doug 'Claw’ Warbrick successfully pitched their idea for a surfboard business to investors in Melbourne. A small loan was used to start Rip Curl, named after the surfing term 'ripping the curl'. Initially Singer and Warbrick focused attention on custom surfboards, establishing subcultural credibility for their fledgling enterprise. The localised customer-base provided the owners with modest incomes, but ample surfing time. Around the same time, fellow Victorian surfer Alan Green developed an idea for producing warmer, user-friendly surfing suits. After completing several prototypes, Green met with Singer and Warbrick at Rip Curl and pitched his idea for a wetsuit company. Warbrick and Singer recognised a market for well-designed surfing wetsuits, 'made BY surfers FOR surfers' (Stewart et al. 2008: 211), and began production in 1969. With limited inventory Rip Curl branded neoprene suits were supplied to a select number of surfboard factories, and a dozen or so surf retail stores (selling boards, boardshorts, and t-shirts) scattered along Australia’s east coast.

During the 1980s Rip Curl expanded into the United States, Europe, and South America issuing spatially restricted brand licenses to local surfing investors. Such licensing equated to renting-out the 'intangible assets’ of the brand (cf. Perrier 1998) while Rip Curl Australia maintained control over product design and marketing. Crucial to the firm's commercial success was their credibility as a market leader in well-made specialised surfing wetsuits. The suits were considered more comfortable and better performing (less restrictive and warmer) than competitor's products. Focusing mainly on surf hardwear, by 2008 Rip Curl enjoyed annual international sales of more than US\$400 million. From modest beginnings as a surfboard manufacturer, the enterprise developed into the world's largest privately-owned surf company.

In addition to its own subcultural legitimacy and market success, Rip Curl also spawned an offshoot: Quiksilver. Alan Green began developing other surf-related products, including surfing shorts, drawing on knowledge of wet-suit production and the Velcro method for sealing the neck area. The prototype was comfortable and allowed a free range of movement. In time, these new apparel items became known as 'board-shorts' because they were intended for surfers. The shorts made an immediate impact with both surfers and non-surfers who wanted a more stylish alternative to traditional swimming trunks, and to identify with surfing subculture. After operating for a year as a division of Rip Curl, using a series of rented shops in Torquay, Green 
moved out on his own, calling the new brand 'Quicksilver', referencing something 'elusive, liquid, mercurial, changing readily’ (Quiksilver 2014: np). To differentiate the surf label from a rock band of the same name, Green dropped the letter c.

As with Rip Curl, Quiksilver boardshorts were hand-delivered exclusively to surf shops. The approach targeted core surfing consumers. The boardshorts could only be sourced from key retail sites known to surfers, which enhanced rarity value. Wearing surf brands marked consumers as different from the mainstream, and 'in the know' within surfing subculture. Nevertheless, long hours on the road personally delivering board-shorts was time-consuming and unsustainable. Australia was a sparsely populated country with a small domestic retail market. To improve efficiency and grow the brand, Green approached another Torquay surfer, John Law, with an offer to join Quiksilver. Law joined Quiksilver at the start of 1976 and used his personal networks to establish distribution deals in Japan, Hawai ‘i, and France. In April 1976, Law gave visiting American pro-surfer Jeff Hakman a pair of Quiksilver shorts. Impressed with the comfort and quick-drying ability of the board-shorts, Hakman asked to purchase a brand license to produce, distribute, and sell Quiksilver surfwear in North America. While infamous for his drug use, Hakman was one of the world's best surfers competing on the international circuit. His reputation for licentiousness and surfing ability added to Quiksilver's credibility as a surfing brand. After Hakman purchased the license he recruited surfer and businessman Bob McKnight, and Quiksilver USA became the first transnational surfing enterprise.

The third surfing brand to later become a publicly listed, multinational enterprise was Billabong. While Quiksilver and Rip Curl had their feet in the cold waters of Torquay, Billabong originated on Queensland's subtropical Gold Coast. Yet again, brand formation was intimately linked to surfing subculture. Founder Gordon Merchant was a talented surfer who worked in several Sydney surfboard factories before moving to the Gold Coast in the late 1960s. In 1973, in partnership with his wife Rena, Merchant began designing and sewing board-shorts for Gold Coast surfers. Unlike Torquay, where board-shorts could rarely be worn in the ocean because of the cold water, in Queensland, surfing shorts were worn year-round. Billabong shorts were originally made by hand, sewn together in a flat through the week and delivered to Brothers Neilsen surf shops along the Gold Coast every Friday, in time for the busy weekend period.

Billabong quickly became popular and the Merchants diversified into T-shirts and other 'surf-styled' clothing. Much like Green in Torquay, Merchant personally distributed Billabong clothing to surf shops along the east coast, restricting supply to bona-fide surf shops. Again, the strategy affirmed the brand's subcultural credibility. Local authenticity was crucial, as one longtime Billabong retailer explained:

Gordon asked if I would stock his range of shorts, and he had some T-shirts as well. I 
agreed. They sold pretty well. Then I mentioned he should have 'Australia' somewhere on the shirt because Australian surfing was becoming a fashionable thing at this time. Soon after that I noticed they'd put Billabong Australia 'since 1973' on some shirts. Those were always the most popular... Gordon was very smart too, because he didn’t just go selling the clothes in any old retail shop. He started out only letting surfboard shops stock the stuff. It was hard to get. People really became stoked on the fact that surfers were the only people wearing this gear. (interview 2013)

Other surfwear companies that entered the market sought to capitalise on the surf craze by allowing department stores to stock masses of their products. Brands such as Hang Ten and Ocean Pacific entered into supply agreements with department store chains, often after being purchased by larger corporate retailers. However, strategies of market saturation consistently failed. Selling in department and discount stores briefly led to higher unit sales but over time falling sales prices and erosion of brand legitimacy among core surfing consumers. While supplying exclusively to smaller, independent surf shops disciplined Billabong and Quiksilver's growth, the approach galvanised a strong sense of authenticity and exclusivity for each label (cf. Hracs et al. 2013). Exclusiveness heightened rarity value and legitimacy as subcultural brands.

Good timing also played a part. By the 1980s, specialist surf shops were multiplying in popular tourist regions and coastal towns. A surf retail network became more established and prominent, enabling Billabong, Quiksilver, and Rip Curl to sell products in larger numbers via distribution to specialist outlets. Markets increased while subcultural cachet remained. Enterprise formation and accumulation strategies for the eventual 'Big Three' surf brands were strongly shaped by the values, beliefs and attitudes entrenched in surfing. Clothing and apparel was hand delivered to specialist 'surf shops'; there were no signed contracts for supply or pricing, only handshake agreements; there was little inventory planning; financing was sourced from friends and family more than formal lenders, and production occurred in garage workshops with work commitments taking a back-seat when the surf was good.

In this early phase of expansion, the Big Three remained tangibly attached to surfing; surfers filled management positions, and they sponsored international contests and surfers. Each brand became an iconic symbol of the surfing subcultural lifestyle. The embeddedness of each enterprise in the subculture was critical to the phenomenal market growth experienced throughout the 1990s and early 2000s. Subcultural enterprise formation involved trading on the credibility associated with being early participants and innovators, leveraging signifiers of anti-mainstream values, and maintaining clear attachments to surfing scenes. Such dynamics were pivotal for brand identity, alongside exchange value and geographic expansion. 


\section{Going global: corporatising a subculture}

Throughout the 1980s, the Big Three pioneered a global subcultural accumulation strategy based on brand licensing deals with investors and specialist distributors in overseas territories, where surfing had grown and offered viable markets. Subcultural diffusion spawned geographic variants with respective values of localism and credibility (Usher and Kerstetter 2015). The Australian network of surf retailers was replicated elsewhere: in southern California, Hawai'i, South Africa, South America and beyond (Figure 1). Global expansion of surf brands took a particular 'market form’. Licensing agreements allowed original equipment manufacturers (OEMs) outside Australia to make and market branded products. Australian parent companies controlled trademarking and IP. Growth was secured by strategic international niche marketing, tapping into surf shops with connections to respective local surf scenes (e.g. Hobie and Golden Breed in California), coupled with sponsorship of world tour surfers and events. Beyond being useful for surfing, branded products traded through international niche retail networks, encouraged subcultural performances and identities through their marketing (Anderson 2016).

\section{$<$ Figure 1 about here >}

From a global subcultural network, the Big Three moved beyond selling to surfers in popular surfing regions. Retail activities expanded geographically, and demographically. Enjoying growing personal wealth but still embodying surfing's risk-taking ethos, the founding surfer-entrepreneurs' ambitions grew, targeting the more generic 'outdoor leisure' market. In this they were joined by other corporate surf-related brands such as Volcom (now owned by luxury goods conglomerate Kering) and Hurley (now owned by Nike). To raise capital Quiksilver listed publicly on the NASDAQ in 1986 (transferring to the NYSE in 1998), deliberately choosing higher-end stores such as Nordstrom to increase markets in the U.S. and Europe. Numerous flagship stores were also opened in major city centres away from beachside retail districts.

Importantly, new executives and managers were recruited from outside surfing subculture. Bernard Mariette, previously an executive at Marks and Spencer and general manager of cosmetics giant L’Oreal, was hired by Quiksilver in 1994 as Vice-President (Europe), promoted to European President in 1999, and Global President in 2001. Mariette oversaw rapid retail expansion, brand acquisitions and product diversification. In 2005, Quiksilver expanded beyond surfing, purchasing French ski manufacturer Rossignol and Cleveland Golf Co. for US\$550 million (Warshaw 2010). Under Mariette, armies of PR experts and market researchers worked to develop brand strategies to colonise new, unfamiliar markets (snow, hiking etc). Quiksilver executives felt the brand had 'outgrown surfing' (Jarratt 2010) and to facilitate expansion investment flowed into new 'concept stores' - called 'Boardriders clubs' - located in high-street retail precincts in New York, London, Paris and Tokyo. In 1985, Quiksilver's total 
sales were just \$20 million, with 65\% from U.S. consumers. But in 2004 they passed the \$1 billion mark, selling in over 90 countries. With fully-fledged licensed divisions in Europe and North America, branding no longer emphasised Australian roots (cf. Pike 2015). Rather Quiksilver oriented itself as an international brand focused on the entire outdoor leisure market.

Main competitor, Billabong, was slower to diversify for two main reasons. First, the brand failed to 'crack' the U.S. market until the late 1980s. Second, early acquisitions focused on brands with similar subcultural roots (e.g. Von Zipper sunglasses, Element skateboards). Such acquisitions didn’t threaten Billabong's subcultural credibility, rather 'strengthened it around the edges and created new platforms for growth' (Jarratt 2010: 224). In time however, Billabong followed Quiksilver in becoming a global corporate firm, acquiring assets, debt-funding expansion and opening a similar network of flagship stores in world cities. In August 2000, Billabong listed on the Australian Stock Exchange, in a A \$440 million float, and became more aggressive with its market strategy. Executives pursued vertical integration, buying-up suburban shopping mall retailers (e.g. Surf, Dive \& Ski and Jetty Surf) to improve distribution, and moving into online retail by acquiring swell.com and SurfStitch. By 2011 Billabong’s integration and acquisition strategy reached its apogee, with 639 retail outlets and a portfolio of a dozen other surf-related brands. Expansion was debt-financed from the standard institutional channels (HSBC, Bank of America Meryll Lynch and Commonwealth Bank), exposing Billabong to greater liabilities and risk.

Initially, increasing debt levels for both publicly listed subcultural brands were serviced by healthy sales growth. Between 1995 and 2000 Quiksilver Europe alone averaged 32\% annual growth. Even after the Global Financial Crisis (GFC), Billabong's sales from ‘chain stores' grew from \$288 million in 2009 to \$618 million by 2011. As each brand went public, accumulation strategies locked into a particular form of market expansion. Returning profits to shareholders meant having to constantly increase sales volumes and market share in wider youth fashion and sports sectors, saturating markets and extending well beyond subcultural origins.

Production also internationalised, generating divisions of labour in ways typical of large, non-surfing fashion firms (cf. Merk 2011). For instance, in the mid-2000s Quiksilver restructured operations to ensure design centres in America, Europe, Australia, and Japan 'developed and shared designs and concepts that are globally consistent' (Quiksilver Annual Report 2010: 3). In 2009, some 84\% of its apparel, footwear, accessories, and hard-good products 'were purchased or imported as finished goods from suppliers principally in China, Korea, Hong Kong, India, Vietnam and other parts of the Far East, but also in Mexico, Turkey, [and] Portugal' (Quiksilver Annual Report 2010: 6). At its height, Quiksilver had 9,600 employees globally, with union representation among the workforce virtually non-existent. Likewise, by 2009 some of 
Billabong's strongest sales growth across its 2,600 retailers was in countries without realistic possibility of surfing in the ocean (e.g. Germany and Austria).

Despite maintaining private ownership, Rip Curl continued to share similarities with the two public enterprises, particularly in terms of fragmenting and outsourcing production of branded products. Rip Curl’s Asia-Pacific CEO Stephen Kay revealed that:

Most of our goods are made by third parties - manufacturers from Morocco through to China. We own a very large wet suit manufacturing facility in Chiang Mai in Thailand which is the largest single employer in the Rip Curl world [650 employees]. And we maintain a very small wet suit factory in Australia that produces maybe half of $1 \%$ of our total requirements. Other than that, it's pretty much all made overseas with China as our Number one supplier. (interview 2009)

Signalling a shift in brand identity, Rip Curl no longer viewed itself as a maker of surfwear, but a 'marketing company'. Each of the Big Three emphasised more generic global branding of their products, rather than connections to local surfing subcultures. Rip Curl’s Stephen Kay elaborated:

Trying to be a global brand with regional sensitivities can be a real challenge. We set about standardising formats and the use of brand and logo around the world and having more of a global team of athletes, a global events platform. When I arrived, there was very little globalisation in that area and nine years later we have quite a high level of globalisation and a lot more guidelines in place. (interview 2009)

Dramatic international expansion and market saturation moved the surfing industry well beyond its countercultural, 'back of the van' roots. The industry became characterised by complex production and distribution networks, far-reaching marketing campaigns, and transnational corporations with interests outside the subculture, in more general 'outdoor lifestyle' markets. What corporate management of the Big Three ignored was that each brand remained dependent on subcultural legitimacy for meaning and value creation (Wood et al. 2016). Surfing subculture underpinned brand identity and heritage and ultimately limited global market saturation.

\section{Market failure: the collapse and limits to subcultural enterprises}

The corporate collapse of surf brands followed, but wasn't wholly precipitated by, the GFC. It was the interaction between depressed consumer spending in the wake of the GFC and the loss of subcultural authenticity among those same consumers, which sealed the fate of Quiksilver and Billabong. Even though surfers by now constituted a smaller percentage of overall sales, they remained the key cultural gatekeepers conferring (or in this case, destroying) brand credibility. Once trend-setting surfers abandoned the brands, in time general non-surfing consumers followed. 
There were earlier signals of vulnerability. For many insiders, public listing was a key threshold: 'That was the turning point for sure. Now we had shareholders to appease. The biggest thing became growth at all costs. In pursuing that [growth] we lost touch with our core consumers: surfers’ (Quiksilver design manager, interview 2014). After listing, Quiksilver’s debtto-capital ratios gradually worsened. In 2004, Quiksilver’s revenue passed the US\$1 billion mark, with total debt at US\$400 million. By 2007, sales had increased to US\$2.4 billion, but overall debt had also ballooned to US\$1.7 billion (figure 2). Even before the GFC impacted consumer spending, Quiksilver executives were desperately seeking a buyer for formerly acquired Rossignol and Cleveland Golf Co. (due to low profitability). The financial crisis merely brought matters to a climax. After 18 months of negotiation Quiksilver executives sold Rossignol and Cleveland Golf Co. in November 2008 for a combined US\$169 million; losing US\$381 million in the deal. By 2009 Quiksilver’s annual interest bill on debts passed US\$100 million, and credit agency Moody’s added it to a watch list of companies most likely to default. Corporate restructuring commenced, involving 1,400 redundancies, wage freezes, a 15\% cut to executive salaries and closure of 50 stores. Still, Quiksilver posted losses for a further six years. When the company filed for Chapter 11 Bankruptcy in 2015, liabilities totalled US\$1.2 billion and assets just US\$922 million.

\section{$<$ Figure 2 and 3 about here $>$}

Billabong also faced financial wipe-out (figure 3). Between 2005 and 2012 retail acquisitions increased total debt by 330\% (to A \$1.05 billion). In 2010 Billabong’s market value was still estimated at A\$6 billion, but three years later had fallen to only A \$272 million. After recording a third straight annual loss in 2014 (A\$233 million) a U.S. private equity consortium, (Oaktree Capital Management, Bank of America, Centerbridge Partners) acquired a controlling stake in Billabong, with asset stripping and company break-up appearing highly likely.

The role of non-surfing executives in the collapse was significant. Each of the Big Three brands became dominated by corporate class executives with no surfing background. For example, Billabong was targeted by Matthew and Scott Perrin, notorious Australian corporate raiders, property developers and 'racetrack touts' (Jarratt 2010: 207). Other CEOs included Launa Inman, former head of Target and Officeworks retail chains, and Neil Fiske, a Harvard Business School graduate (and non-surfer) and former boss of Bath \& Bodyworks. Power struggles within the Big Three also saw corporate executives oust board members and mid-level managers with surfing legitimacy. In 2013 Quiksilver USA founder-surfer Bob McKnight was replaced as CEO by ex-Nike executive and former head of Disney Consumer Products, Andy Mooney. At Billabong, Inman ousted 20-year company veteran (and well-known surfer) Derek O’Neill. When corporate balance sheets worsened, executives became increasingly beholden to 
shareholders, Wall Street investment banks, and private equity consortiums. During investor earnings calls, such actors showed no interest in surfing per se, and fixated on improving investment returns through lowering production costs and expanding retail distribution. Key decision-makers for each enterprise were not subcultural participants and lacked an understanding of the brand's core consumers who co-created success and underpinned the value of branded products in highly competitive general retail markets.

With values pertaining to surfing replaced with imperatives of market share and growth, the corporatised, multinational brands lost meaningful connections to subcultural origins. As one former Billabong employee put it: ‘we completely sold out. That's the reality. Surfers don’t want to wear the gear anymore. Sooner or later the broken connections eat away the relevance and value of the brand... once that relevance is gone, you can't easily get it back.' (interview 2014). Now controlled by non-surfers, Billabong and Quiksilver sought acquisitions, market saturation and product homogenisation, but in the process rarity value, subcultural credibility and place association were eroded. While core surfing consumers effectively co-created the popularity and value of Quiksilver and Billabong they also played a key role co-destroying them.

\section{1 'Selling out': the loss of subcultural credibility}

Whereas earlier processes of commodifying surfing involved surfers directing market and branding strategies (as start-up entrepreneurs emerging from within the subculture), the surf mega-brands fell under the control of non-surfing executives who distanced themselves from core consumers. The international successes of the Big Three owed much to their subcultural legitimacy and association with iconic surfing places. Such connections afforded brands significant credibility among 'core’ surfing consumers, lost in the wake of corporatisation, appointment of mainstream retail executives, increasing involvement of global investment banks, and the necessity to abide market imperatives.

Interviews with corporate executives, post-collapse, support this argument. Executives slowly became aware of the need to 'reconnect with core consumers':

It's not just about buying the product. It's also about the whole ability to access information regarding the sport that they [consumers] are passionate about. People want to be able to go on to a Billabong site and find out when the waves are going to be up. They want to be able to go onto the site and see the actual surfing taking place in Tahiti. This is all about the experience. It's all about making them feel part of the tribe, and that's what we need to work on [getting back]. (CEO Launa Inman, shareholders call 2012) Despite recognising a need to 'focus on the authentic core', Billabong's financial haemorrhaging continued. Compelled to deliver shareholder returns, market imperatives of geographic 
expansion, economies of scale and homogenised designs for efficient supply chains were prioritised. Opening new markets and saturating them with branded products was an inevitable strategy to produce figures on volume and sales that calmed panicked investors. The trouble was, such strategies transgressed what we argue were real limits to subcultural enterprises: limits informed by values of credibility, rarity, and a genuine connection to surfing people and places.

An instructive example involves Billabong's market strategy in South Africa. In the early 2000s Billabong achieved considerable success in South Africa after founder Gordon Merchant licensed Cheron Kraak to design, manufacture and sell Billabong clothing via her network of 16 independent surf shops. In 2006 Kraak helped Billabong win a 'Khuza' fashion award as South Africa's most popular female youth brand. A large manufacturing facility near the famous waves of Jeffrey’s Bay employed 220 local workers who followed a workplace routine typical of subcultural enterprises:

We have a great policy at work; when the surf pumps, we go surfing! We are a surf company, and besides, it's no use trying to keep them indoors when Supers [iconic surf break] is 6 to 8 feet! As long as they make up their time, it's all good. (Cheron Kraak, interview 2006)

Nevertheless, after consolidating global operations, Billabong bought back the South African licence in 2007. Local design teams were merged into global production networks that supplied Billabong's growing portfolio of mall and main street retail stores with generic designs. Localism, central to the values of surfing (Beaumont and Brown 2015), was overridden by the desire from corporate headquarters to standardise global product to achieve efficiency gains.

Feeding increasingly standardised designs for mass markets were the global production networks that undermined the authenticity associated with surfing's place origins (cf. Yeung 2014). Billabong may have had 'Australia - since 1973' as part of their logo on t-shirts and shorts but 'Made in China' on the inside label sent a message to surfers that the brand, once a proud export of the Australian surfing scene, had become another victim to cheap, offshore production. Quality demonstrably suffered - a critical issue to surfers for whom performance in the ocean, and durability amidst exposure to saltwater and sun, were paramount. T-shirts and board-shorts instead looked like any other ‘fast fashion’ clothing, and simply didn’t last. Meanwhile Rip Curl was the subject of damning national headlines revealing Chinese subcontractors' use of indentured North Korean labour in producing t-shirts and apparel (McKenzie and Baker 2016).

The notion of 'selling-out' thus epitomised the feelings of surf industry figures interviewed for the research. As one former Billabong employee put it:

You could see the fall coming. We started standardising our designs as the execs were obsessed with market expansion. Shareholders want dividends. A lot of us just shook our 
heads: 'this is what it looks like to sell-out'. We completely lost our roots. How can a brand be [part of] surfing culture and become this capitalist monster acquiring indie brands, opening swanky stores in New York and taking production to the cheapest factories in places uninterested in surfing?

As the Big Three expanded and dispersed into numerous products, disenchanted industry insiders felt a sense of grounded connection to subcultural roots was lost. As one retailer concisely summarised, 'they lost their soul in greed'.

Unsurprisingly, products sold by the Big Three became increasingly unfashionable among younger surfing consumers. As surf writer Phil Jarratt (2010: 211) argued, '[what] pissed a lot of people off was the fact that they [the Big Three] had such muscle in the market that they could dominate virtually everything they touched, and homogenise it. An increasing number of surfers didn’t want to be homogenised. It wasn’t in their genes'. Yet beholden to investors and shareholders, executives focused on market share and growing revenue. With diminishing returns from traditional surf retailers, expansion was instead pursued by supplying to department stores. ${ }^{2}$ Leveraging heritage in surfing subculture Quiksilver supplied to Macy’s. Billabong soon followed, selling via discount outlets such as TJ Maxx in North America and El Corte Inglés in Western Europe. By 2013 sales from such 'close-out channels' (heavily discounted products sold in department stores), comprised nearly 20\% of Quiksilver and Billabong's annual revenues. When asked about the department store strategy and potential for it to dilute the brand's reputation, then Billabong CEO, Launa Inman, confessed:

Yes, they ['close-out' sales] are looking a little higher than we would like... but we know that and we're looking to actually reduce that. But that is a result of merchandise, when we've been overstocked, that we've had to clear excess inventory. (interview 2012)

Excess stock was indicative of falling orders as demand fell for branded Billabong and Quiksilver products. Discounting cut into profit margins, and sales and market share for Quiksilver and Billabong worsened. For example, despite the global surf retail market expanding by $17 \%$ in the post-GFC period (2009-2016) to reach US\$13 billion (Global Industry Analysts 2016), sales for Billabong and Quiksilver declined by 35\% and 32\% respectively. Equally significant to macroeconomic conditions was eroding credibility of each brand among surfers and surfing subculture.

Facing growing debts, falling sales and profit margins, corporate executives within the Big Three belatedly admitted errors in seeking endless global expansion and standardisation at the expense of subcultural connections. Reporting to shareholders in 2012 Billabong conceded abandoning its subcultural roots had eroded the value of the brand:

When Billabong started in 1970s it was unique, it was one of the first to market and it had phenomenal heritage and great performance. It was a differentiated product, but... we just 
need to make sure that we focus once again on what made this Company great. It's all about the product and it's about ensuring that you understand what the consumers want... What we now need to do is to use that information better. (Launa Inman) Likewise, in 2011 Quiksilver's (then) chief executive Bob McKnight belatedly recognised the need to 'reinforce our heritage and authenticity to the consumer' (Hamanaka 2011: 65). After McKnight was himself ousted to make way for an ex-Nike/Disney CEO, the company attempted to retrieve credibility within surfing through Pierre Agnes, a former French surfing champion and critic of earlier corporate expansionist approaches. While corporatised surf brands have attempted to 're-focus on the authentic core' and 're-orient... towards building strong global brands that are locally responsive' (Billabong 2013: np), such language merely indicates the deep contradictions of subcultural enterprises (cf. Harvey 2014). There are inherent tensions between market imperatives (distribution networks, inventory, margins and sales volumes), and subcultural authenticity, legitimacy and place connections.

Of the Big Three, Rip Curl is now faring best. After re-investment in wetsuit production, a core product for surfers, Rip Curl announced a net profit of A \$23 million for 2015/2016 (on sales of A $\$ 446$ million). Affirming the importance of subcultural authenticity and credibility in shaping market performance, Rip Curl’s CFO Tony Roberts explained: 'we are more of a core surf brand than either key competitor. They both grew bigger than us but in growing bigger they stretched into that non-core [surfing] market more than we have... we have been very true to our roots in terms of our core products. For example, our wetsuits are our champion products and have been since the company was founded'. Rip Curl's profit turnaround, captured by their slogan 'Made by Surfers for Surfers', has been underpinned by a focus on branded products essential for surfing participation. Straight-jacketed by shareholders and private equity, the future of the two wholly-corporatised brands is much less certain. At the time of writing, Billabong had announced another \$77.1 million loss for 2017, with combined losses since 2011 totalling A \$1.46 billion. Meanwhile, Quiksilver emerged from bankruptcy re-organisation in February 2016 with legal protections enabling dissolution of US\$520 million in debt. The brand has since been acquired by private equity firm Oaktree Capital Management, who delisted and moved Quiksilver under a new corporate structure branded: 'Boardriders, Inc'. The re-branding strategy, according to the firm will help them 'pivot from restructuring to growth’ by re-animating Quiksilver’s 'boardriding culture and heritage’ (Oaktree Capital Press Release 2017: np). Marketing rhetoric won't, however, resolve the underlying problem of lost subcultural credibility. Rebuilding the collapsed subcultural enterprise will be untenable without also rebuilding subcultural legitimacy among the brand's core consumers: surfers. 


\section{Conclusions}

Geographers are increasingly exploring the social and spatial contexts of capitalist brands, including how place and consumer associations shape market strategies and commercial fortunes (Jackson 2004; Pike 2015; Crewe2017). This article has examined one underexplored source of brand value creation within contemporary capitalism: subcultures. With subcultural logics, meanings, and values pervading an increasing array of consumer goods, social 'scenes' and leisure activities (cf. Lawler 2012), further geographical analysis of the intersection between subcultures, brands and branding is needed. Subcultural values of credibility, rarity, and legitimacy now infuse a host of industries, from musical instruments and 'maker' scenes to extreme sports and tourism experiences (McRobbie 1998; Booth 2005; Lange and Burkner 2015). A growing range of markets find their 'shape' being formed by semiotic meanings and identityaffirming qualities (Scott 2014). Commercial opportunities will arise for brands offering social distinction, product quality, and connections to subcultures and their active consumer groups. Across such examples, tensions between narratives of subcultural and place origins, and marketisation, globalisation and standardisation, will play out in nuanced ways.

In the case of surf brands, subcultural meanings and values are a potent reservoir from which commercial gains can be sourced via branded products. Commodification and marketisation of surfing during the twentieth century benefited from the subculture's credibility, sun-drenched imagery and antithetical attitudes to mainstream society (Booth 2005; Lawler 2012). From informal origins, subcultural enterprises grew, and spurred by initial successes within national and international niche retail markets, became corporatised, publicly listed companies reliant on selling surfing to the masses. Firms expanded geographically, becoming progressively obliged to shareholders and investment banks, locked-in to the saturation of clothing in nondescript shopping malls and department stores. In pursuing surplus value, high volume sales, and market share, both product quality and brand credibility declined. As each brand was abandoned by surfing consumers, they lost subcultural legitimacy. Facing financial ruin, they pursued high-volume, lower-cost strategies that flooded retail markets, undermining rarity value. And once core surfers, the key trendsetters, had abandoned them, brands thereafter lost the 'cool' factor upon which sales to the masses depended.

Subcultures enable pathways to distinctive enterprise formation, and influence the shape of incipient markets. At the same time, their subversive nature also means they impart inherent tensions and limits in the brands they spawn. Surf brands relied on leveraging authentic subcultural roots to drive into new niche markets and achieve commercial success. But market growth relied on, and empowered, core surfing consumers who not only co-created each brand by (re)ascribing subcultural meanings and values, alongside product purchasing (Pike 2015), but co- 
destroyed them as corporatisation and mass-market saturation eroded all vestiges of surfing legitimacy.

Conventional explanations that the Big Three surf firms became victims to financial risk, and the volatility of international retail markets, represent only partial accounts of collapse. Flat consumer spending in key European and North American markets in the wake of the GFC clearly played a role reducing revenue and eroding profit-margins on branded surf products. But we contend an equally significant factor in brand failure was the loss of subcultural credibility and legitimacy among surfers. As profit-seeking brands with subcultural origins, the Big Three failed to manage the fine balance between, on the one hand, debt-funded global expansion and market growth for shareholder dividends, and on the other hand, maintaining subcultural authenticity and relevance to core consumers. Indeed, the latter - subcultural legitimacy - was what originally afforded branded products high exchange value in relation to their actual utility for subcultural participation. Rather than privileging one explanation over the other, this analysis has been attentive to interactions between market processes and subcultural roots in explaining brand collapse. Surf brands demonstrate that analytical attention to ascribed meanings, values, and contradictions, and the ongoing degree to which core consumers see brands as authentic, is critical to understanding the market shape and longer-run commercial fortunes of brands with subcultural origins.

To be profitable, subcultural brands must leverage their credibility, authenticity and origins within particular subcultural scenes (Driver 2011). Increasingly global networks of niche retailing offer opportunities to expand geographically, without necessarily eroding links to subcultural scenes and places. But over time, subcultural values of risk-taking and insouciance stoke entrepreneurs' inflated ambitions beyond prudent limits. Collapse in brand authenticity, sales and financial stability ensues not just from difficult retail conditions, but from contradictions unleashed by subsequent public listings, the growing influence of non-subcultural executives, shareholders and investment banks, and market strategies deemed necessary to cope with ballooning debt and to deliver profit and growth. Enterprises are drawn to increase market share and volume, dependent on generating efficiencies through low-cost offshore production. At the same time, rarity value of branded products is eroded and brand reputation diminished. Once subcultural members perceive brands as 'selling-out', cachet and profitability is consistently undermined. The contradictions of subcultural enterprises are shaped both by corporate capitalism's demand for market expansion and shareholder returns (cf. Harvey 2014), and the meanings and values pertaining to subcultures (Driver 2011). Subcultures spawn brands with distinctive accumulation pathways and market strategies, simultaneously unleashing inherent tensions that limit endless mass-market expansion and the global homogenisation of branded 
products. Adopting a culturally-inflected geographical political economy approach (cf. Jessop and Sum 2010; Scott 2014; Pike et al. 2016) has enabled the tracing of interactions between subcultural dynamics informing brand formation and value-creation, and market strategies of debt-financing, global expansion, standardisation, and public-listing that propel both growth and decline. Geographers, we contend, ought to take more seriously how subcultures become a source of profit-making enterprise, as well as subsequent corporate collapse.

\section{Acknowledgements}

We thank all those who gave their time for interviews and provided insights for the article. Thanks are extended to the two anonymous referees and handling editor Sarah Hall for constructive feedback on earlier versions of the article. Responsibility for interpretations and arguments presented remain ours.

\section{Notes}

1. It's important to distinguish between enterprise forms emanating from certain cultural and creative industries, focused around the generation of intellectual property content (such as media and film) and those emanating from subcultural origins, where protagonists seek to pursue commercial possibilities from within the subculture, initially at least. In this way, record labels established by subcultural entrepreneurs may be analogous to the surf enterprises discussed here while, for example, media and entertainment conglomerates such as News Corporation, with no obvious subcultural origins, may not (even though they also trade in expressive, semiotic or 'cultural' content).

2. In 2016 the total surf retail market in the U.S. was estimated at US\$7.15 billion (SIMA 2017). Of this total specialty surf stores (those with more than $50 \%$ of sales derived from surf-branded products) had $24 \%$ of the market or US\$1.72 billion. Of the revenue from 'core' specialty shops the sale of branded hardware for surfing (e.g. surfboards, wetsuits, fins) comprised 34\% of sales or US\$584 million. By comparison department and chain stores (e.g. Macy’s, Nordstrom) totaled $40 \%$ of the overall market for surf-branded products or US\$2.86 billion. The remainder of sales was from online retailers, general fashion, and sporting and leisure stores.

\section{References}

Anderson, J. (2016) On trend and on the wave: carving cultural identity through active surf dress. Annals of Leisure Research 19(2):212-234.

Beaumont, E and Brown, D.H.K. (2015) 'Once a Local Surfer, Always a Local Surfer': Local Surfing Careers in a Southwest English Village. Leisure Studies 27(1):68-86.

Bader, I. and Scharenberg, A. (2010) The Sound of Berlin: Subculture and the Global Music Industry. International Journal of Urban and Regional Research 34(1):76-91.

Billabong (2016) Behind the Brand: Investor information. Available: http://www.billabongbiz.com/investorinfo (Accessed between 2012 and 2016).

Booth, D. (2005) 'Paradoxes of Material Culture: The Political Economy of Surfing'. In

The Political Economy of Sport, edited by J. Nauright and K. Schimmel, 104-125. Hampshire: Palgrave Macmillan.

Cova, B., Kozinets, R., and Shankar, A. (2007). Consumer tribes. London: Elsevier.

Crewe, L. (2003) Geographies of retailing and consumption: markets in motion. Progress in Human Geography 27(3):352-362.

Crewe, L. (2017) The Geographies of Fashion: Consumption, Space and Value. London: Bloomsbury.

Driver, C. (2011) Embodying hardcore: rethinking 'subcultural' authenticities. Journal of Youth Studies 14(8):975-990.

Fagan, R.H. and Le Heron, R. (1994) Reinterpreting the geography of accumulation: the global shift and local restructuring. Environment \& Planning D: Society and Space 12:265-285. 
Finney, B, and Houston, J. D. (1996) Surfing: A History of the Ancient Hawaiian Sport. San Francisco: Pomegranate.

Greenblat, E. (2014) Ahmed Fahour offloads large Rip Curl stake in $\$ 2.99 \mathrm{~m}$ sale, Sydney Morning Herald, 18 March (Accessed 5 June 2014).

Gibson, C. and Warren, A. (2014) Making Surfboards: Emergence of a Trans-Pacific Cultural Industry. Journal of Pacific History 50(1):1-25

Global Industry Analysts (2016) Surfing: A Global Strategic Business Report, May 2016. Available: http://www.strategyr.com/MCP-6536.asp\#sthash.kR4m918w.dpbs (Accessed Oct 2016)

Hall, S. and Jefferson, T. (1975) Resistance through Rituals: Youth Subcultures in Postwar Britain, Routledge, London.

Hamanaka, K. (2011) Quiksilver Comeback: New Stores Planned. Orange County Business Journal 34:64-65.

Perrier, R. (1998) Brand Licensing. In S. Hart, S. and J. Murphy, J. (Eds) Brands: The New Wealth Creators. New York: Springer, pp. 104-113.

Harvey, D. (2014) Seventeen Contradictions and the End of Capitalism. Oxford: Oxford University Press.

Hudson, R. (2012) Critical Political Economy and Material Transformation. New Political Economy 17(4): 373-397.

Hracs, B., Jakob, D. and Hauge, A. (2013) The rise of exclusivity-based strategies to compete in the contemporary marketplace for music and fashion. Environment and Planning $A$ 45(5):1144-1161.

Imada, A. L. (2012) Aloha America: Hula Circuits through the U.S. Empire. Durham: Duke University Press.

Jackson, P. (2004) Commercial cultures: Transcending the cultural and the economic. Progress in Human Geography 26(1):3-18.

Jarratt, P. (2010) Salts and Suits. Melbourne: Hardie Grant.

Jessop \& Sum, N. G. (2010) Cultural Political Economy and the Potential of the Cultural Turn. New Political Economy 15(3):445-451.

Khouri, A. (2015) Wipeout: Quiksilver files for Chapter 11 Bankruptcy in U.S. Los Angeles Times, 9 September (Accessed 10 September 2015).

Lange, B. and Burkner, H. J. (2015) Value Creation in Scene-Based Music Production. Economic Geography 89(2):149-169.

Lash, S. and Urry, S. (1994) Economies of Signs and Space. Sage, London Routledge.

Lawler, K. (2012) The American Surfer: Radical Culture and Capitalism. New York:

McKenzie, N. Baker, R. (2016) Rip Curl using 'slave labour' to manufacture clothes in North Korea. Sydney Morning Herald, 21 February (Accessed 22 February 2016).

McRobbie, A. (1998) British Fashion Design: Rag Trade or Image Industry? London: Routledge.

Merk, J. (2011) Production beyond the horizon of consumption: spatial fixes and antisweatshop struggles in the global athletic footwear industry. Global Society 25(1):73-95.

Moor, L. (2007) The Rise of Brands. London: Berg.

O’Neill, P. and Gibson-Graham, JK. (1999) Enterprise discourse and executive talk: Stories that destabilize the company. Transactions of the Institute of British Geographers 24(1):11-22.

Pearson, K. (1979) Surfing Subcultures of Australia and New Zealand. Brisbane: University of Queensland Press.

Palmås, K. (2014) From criminality to creativity: how studies of surfer subcultures reinvented invention. Sport in Society 17(10):1290-1305.

Pike, A. (2009) Geographies of brands and branding. Progress in Human Geography 33(5):619-645 
Pike, A. (2015) Origination: the Geographies of Brands and Branding. Oxford: Wiley.

Pike, A., MacKinnon, D., Cumbers, A., Dawley, S. and McMaster, R. (2016) Doing evolution in economic geography. Economic Geographer 92:123-144.

Polanyi, K. (1977) The Livelihood of Man. New York: Academic Press.

Quiksilver Inc. (2015) Investor Relations: SEC Filings. Available: http://quiksilver.com/investor/SEC (Accessed between 2010 and 2016).

Scott, A. J. (2014) Beyond the Creative City: Cognitive-Cultural Capitalism and the New Urbanism. Regional Studies 48(4):565-578.

Shaw, W.S. and Menday, L. (2013) Fibro Dreaming: Greenwashed Beach-house Development on Australia's Coasts. Urban Studies 50:2940-2958.

Sheppard, E. (2011) Geographical Political Economy. Journal of Economic Geography 11(2):319-331.

Stewart, B, Skinner, J. and Edwards, A. (2008) Cluster Theory and Competitive Advantage: The Torquay Surfing Experience. International Journal of Sport Management and Marketing 3(2):201-220.

Surf Industry Manufacturers’ Association (2017) Consumer Insights Study. Available: http://sima.com/sima-consumer-insights-study/ (Accessed Oct 2016)

Thornton, S. (1995) Club cultures: music, media and subcultural capital. Wesleyan University Press.

Tokatili, N. (2014) ‘Made in Italy? Who cares!' Prada’s New Economic Geography. Geoforum 54(1):1-9.

Trask, H.K. (1996) From a Native Daughter: Colonialism and Sovereignty in Hawai ‘i. Honolulu: University of Hawai'i Press.

Usher, L.E. and Kerstetter, D. (2015) Surfistas Locales: Transnationalism and the Construction of Surfer Identity in Nicaragua. Journal of Sport and Social Issues 39(6):455-479.

Walker, I. (2011) Waves of Resistance. Honolulu: University of Hawai'i Press.

Warren, A. (2014) Working culture: the agency and employment experiences of nonunionised workers in the surfboard industry. Environment and Planning A 46(10):2300-2316.

Warren, A. and Gibson, C. (2014) Surfing Places, Surfboard Makers. Honolulu: University of Hawai'i Press.

Warshaw, M. (2010) History of Surfing. San Francisco: Chronical Books.

Walton, T. and Shaw, W.S. (2016) Land-beach-risk-scape: deciphering the motivators of risk-taking at the beach in Australia. Social \& Cultural Geography 18(6):869-886.

Wood, S., Wrigley, N. and Coe, N. (2016) Capital discipline and financial market relations in retail globalization: insights from the case of Tesco. Journal of Economic Geography 17(1):31-57.

Yeung, H. (2014) Governing the market in a globalizing era: Developmental states, global production networks and inter-firm dynamics in East Asia. Review of International Political Economy 21(1):70-101. 